\title{
Patient Quality of Life Improvement in Bullous Disease: A Review of Primary Literature and Considerations for the Clinician
}

Jessica J Padniewski $\mathbb{D}^{\prime}$

Rob L Shaver ${ }^{2}$

Brittney Schultz ${ }^{2,3}$

David R Pearson ${ }^{2,3}$

'Department of Internal Medicine, Hennepin Healthcare, Minneapolis, MN, USA; ${ }^{2}$ University of Minnesota Medical School, Minneapolis, MN, USA;

${ }^{3}$ Department of Dermatology, University of Minnesota, Minneapolis, MN, USA
Correspondence: David R Pearson University of Minnesota Medical School, 516 Delaware St SE MMC 98, Minneapolis, MN, 55455, USA Email pearsond@umn.edu

\begin{abstract}
Autoimmune and inherited bullous disorders are rare skin diseases that may have a profound negative impact on quality of life (QOL). Common symptoms include pain, pruritus, and scarring, and complications may result in the loss of the ability to perform daily tasks. Diagnosis may have a negative psychological impact, and ongoing management may require a significant allocation of time and resources by both patients and providers. To provide patient-centered care, consideration of these factors is of utmost importance for the dermatologist treating patients with bullous disorders. Herein, we present a review of the primary literature evaluating QOL in autoimmune and inherited bullous disorders, including pemphigus, pemphigoid, epidermolysis bullosa, and Hailey-Hailey disease.
\end{abstract}

Keywords: bullous disease, autoimmune blistering disease, pemphigus, pemphigoid, epidermolysis bullosa, Hailey-Hailey, quality of life, ABQOL, TABQOL, DLQI

\section{Introduction}

Autoimmune and inherited bullous disorders represent rare mucocutaneous diseases that may have a significant negative impact on patients' quality of life (QOL). ${ }^{1,2}$ There are various physical, social, and psychiatric factors that contribute to patients' perceived QOL. In order to provide patient-centered care, consideration of these factors is of utmost importance in the treatment of patients with bullous disorders.

In patients with bullous disorders, QOL may be assessed through general medical and dermatology-specific indices, as well as through more specific instruments as evidenced in Table 1. Which QOL assessment best represents patients' experiences remains controversial. For example, Patsatsi et al demonstrated the Autoimmune Bullous Disease Quality of Life (ABQOL) correlated with QOL over time, while Dermatology Life Quality Index (DLQI) assessments did not. ${ }^{3}$ In contrast, Ferries et al prospectively assessed the correlation between disease severity scores in pemphigus (Pemphigus Disease Area Index, PDAI), bullous pemphigoid (Bullous Pemphigoid Disease Area Index, BPDAI), and mucous membrane pemphigoid (Mucous Membrane Pemphigoid Disease Area Index, MMPDAI) to ABQOL, Treatment of Autoimmune Bullous Disease Quality of Life (TABQOL), DLQI, and Skindex-29 scores. They concluded that there may be no advantage of the ABQOL over the DLQI or Skindex-29. ${ }^{4}$

An informed understanding of the complexities of how autoimmune and inherited bullous disorders affect QOL is critical to providing patient-centered care. This facilitates shared decision-making between patient and provider and is 
Table I A Brief Overview of Frequently Used QOL Assessment Tools

\begin{tabular}{|c|c|c|}
\hline $\begin{array}{l}\text { Dermatology Life Quality Index } \\
\text { (DLQI) }^{2,4,7,8,12,13,14,18,20,21,24,30}\end{array}$ & $\begin{array}{l}\text { The DLQI consists of } 10 \text { questions evaluating different } \\
\text { aspects of health-related QOL over the preceding } \\
\text { week. }\end{array}$ & $\begin{array}{l}\text { Numeric score between } 0 \text { and } 30 \text {. Scores }>10 \text { suggest } \\
\text { that a patient's life is being severely affected by a skin } \\
\text { condition. Higher scores correlate with increased } \\
\text { impairment in QOL. }\end{array}$ \\
\hline $\begin{array}{l}\text { General Health Questionnaire } \\
(\mathrm{GHQ}-28)^{6,18}\end{array}$ & $\begin{array}{l}\text { The GHQ- } 28 \text { evaluates general mental health over the } \\
\text { last few weeks and is a measure used to detect } \\
\text { possible psychiatric disorders. It includes } 28 \text { items } \\
\text { assessed on a 4-point scale (0-3). The items assess the } \\
\text { ability to carry out normal functions and the } \\
\text { appearance of new distressing experiences. }\end{array}$ & $\begin{array}{l}\text { Numeric score between } 0 \text { and } 84 \text {. Scores }<23 \text { are less } \\
\text { concerning for psychiatric stress as compared to } \\
\text { scores }>24 \text { which should prompt concern for } \\
\text { psychiatric distress. Higher scores correlate with } \\
\text { increased levels of distress. }\end{array}$ \\
\hline $\begin{array}{l}\text { Medical Outcome Study } 36- \\
\text { item Short-form Survey (SF- } \\
36)^{6,7,13,19,30,71}\end{array}$ & $\begin{array}{l}\text { The SF- } 36 \text { consists of } 36 \text { items combined into } 8 \\
\text { scored scales. Scales include vitality, physical } \\
\text { functioning, bodily pain, general health perceptions, } \\
\text { physical role functioning, emotional role functioning, } \\
\text { social role functioning, and mental health. }\end{array}$ & $\begin{array}{l}\text { Numeric score between } 0-100 \text {. Mean score for the } \\
\text { general population is } 50 \text {. Lower scores correlate with } \\
\text { increased levels of disability. }\end{array}$ \\
\hline Skindex-29 $4,6,7,13,14,30,36$ & $\begin{array}{l}\text { The Skindex- } 29 \text { consists of } 29 \text { questions that assess } \\
\text { the health-related QOL of patients with skin diseases } \\
\text { by evaluating } 3 \text { domains; degree of symptoms, } \\
\text { psychosocial functioning, and emotional status. }\end{array}$ & $\begin{array}{l}\text { Numeric score between } 0-100 \text {. A score between } 0- \\
24 \text { correlates with little impact on QOL, } 25-31 \text { with } \\
\text { mild, } 32-43 \text { with moderate, and } 44-100 \text { with severe. } \\
\text { Higher scores represent worse QOL. }\end{array}$ \\
\hline $\begin{array}{l}\text { Autoimmune Bullous Disease } \\
\text { Quality of Life } \\
\text { (ABQOL) }^{4,13,14,15} \\
\text { Treatment of Autoimmune } \\
\text { Bullous Disease Quality of Life } \\
\text { (TABQOL) })^{4,15}\end{array}$ & $\begin{array}{l}\text { Both the } A B Q O L \text { and } T A B Q O L \text { assess } Q O L \text { on } \\
\text { a Likert scale with scores ranging from } 0-3 \text {. Each } \\
\text { questionnaire includes } 17 \text { specific questions. ABQOL } \\
\text { questions focus on pain, itching, healing, depression, } \\
\text { and anxiety while the TABQOL questions focus on the } \\
\text { number of medications, financial burdens, fatigue, } \\
\text { focus, and fears surrounding relapse. }{ }^{58} \\
\text { The ABQOL and TABQOL assessments have been } \\
\text { validated in various languages including } \\
\text { English, } \\
\text { only), }{ }^{63} \text { Greek, }{ }^{3} \text { and Polish. }{ }^{64}\end{array}$ & $\begin{array}{l}\text { Both have a numeric score between } 0-5 \mathrm{I} \text {. Higher } \\
\text { scores represent worse QOL. }\end{array}$ \\
\hline $\begin{array}{l}\text { The Quality of Life Evaluation } \\
\text { in Epidermolysis Bullosa } \\
\text { (QOLEB) }^{24,25,26,28,29,30,31,67,74,75}\end{array}$ & $\begin{array}{l}\text { The QOLEB includes } 17 \text { questions on a Likert scale } \\
\text { with scores ranging from } 0-3 \text {. It is specifically used to } \\
\text { assess patients suffering from epidermolysis bullosa } \\
\text { (EB). }{ }^{24} \text { Also validated in Dutch, }{ }^{26} \text { Farsi }{ }^{65} \text { and } \\
\text { Portuguese. }{ }^{25}\end{array}$ & $\begin{array}{l}\text { Numeric score between } 0-5 \text { I. Higher scores } \\
\text { represent worse QOL. }\end{array}$ \\
\hline $\begin{array}{l}\text { The Infants and Toddlers } \\
\text { Dermatology Quality of Life } \\
\text { (InTo-DermQoL) } 66,67,68,69\end{array}$ & $\begin{array}{l}\text { InTo-DermQoL questionnaire is an epidermolysis } \\
\text { bullosa-specific tool, which was created and validated } \\
\text { by Chernyshov et al }{ }^{66-68,69} \text { There are } 3 \text { versions based } \\
\text { on age groups; } 10 \text { items for children }<1 \text {-year-old (max } \\
\text { score } 30 \text { ), } 12 \text { items for children I-2 years old (max } \\
\text { score } 36 \text { ) and } 15 \text { items for children of } 3-4 \text { years old } \\
\text { (max score } 45 \text { ). }{ }^{68,69} \text { Includes } 17 \text { questions on a Likert } \\
\text { scale with scores ranging from } 0-3 \text {. }\end{array}$ & $\begin{array}{l}\text { Numeric score between } 0-45 \text { based on age group. } \\
\text { Higher scores represent worse QOL. }\end{array}$ \\
\hline
\end{tabular}

essential to develop a long-term therapeutic strategy for these chronic diseases. Herein, we review the primary literature evaluating QOL in autoimmune and inherited bullous disorders, including pemphigus, bullous pemphigoid (BP), epidermolysis bullosa (EB), and HaileyHailey disease (HHD). 


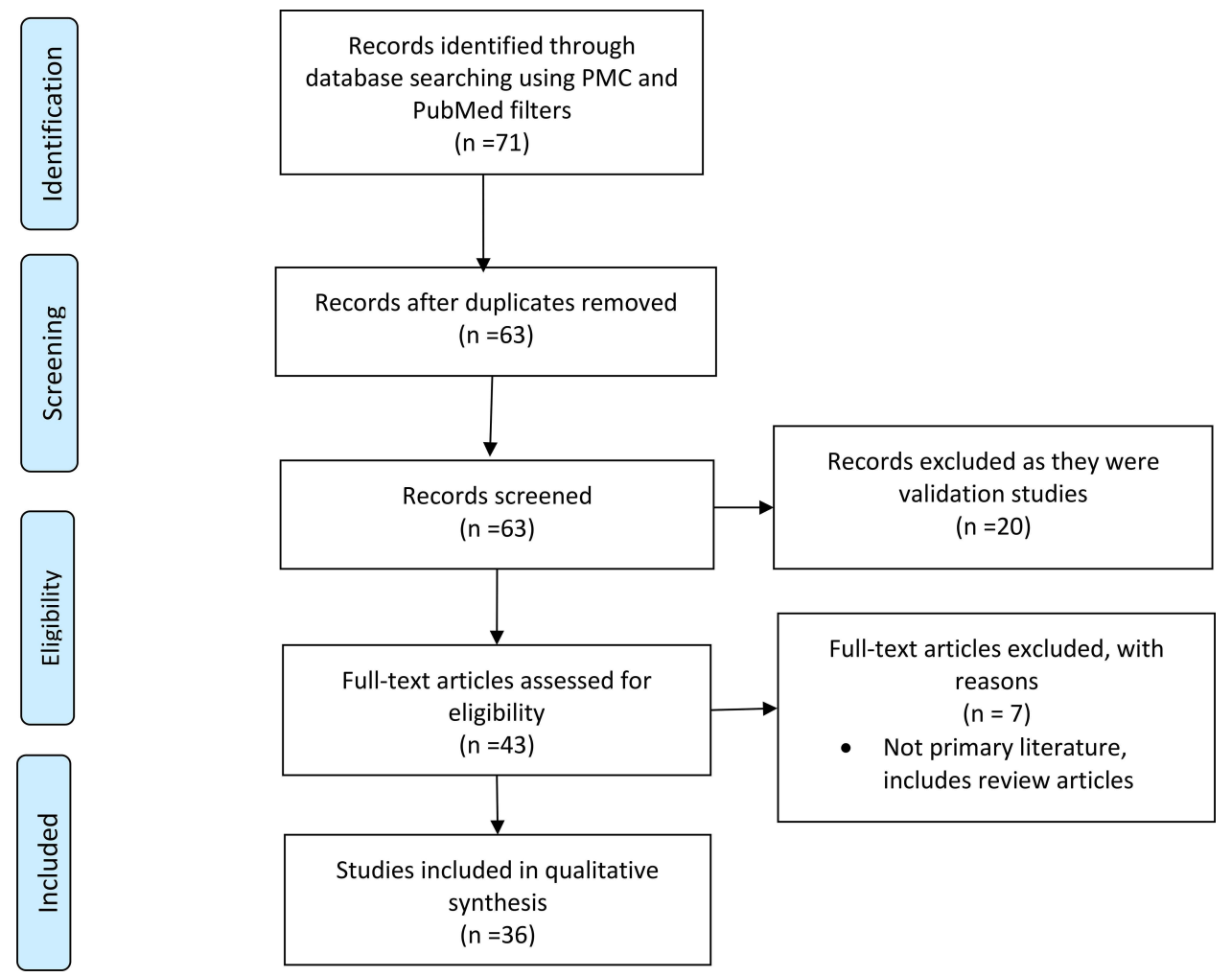

Figure I PRISMA flow diagram for the primary literature review detailing the database searches, the number of abstracts screened, and the full texts retrieved. Notes: Adapted from: Liberati A, Altman D, Tetzlaff J, et al. The PRISMA statement for reporting systematic reviews and meta-analyses of studies that evaluate health care interventions: explanation and elaboration. Journal of Clinical Epidemiology. 2009;62(10)el-e34. Creative Commons.

\section{Methods}

A primary literature review was conducted in English using the NCBI database (PMC and PubMed filters) using the keywords "quality of life" AND "bullous," "pemphigus," "pemphigoid," "epidermolysis," "Hailey-Hailey," "blister," OR "blistering." There were no limitations set on date of publication. To be included, articles must have included QOL data specific to a blistering disease. Non-primary literature, such as reviews, meta-analyses, and commentary articles lacking original evidence, were excluded. Two independent authors (JJP and RLS) evaluated titles and abstracts of the articles retrieved during the search. The full article was evaluated if titles and abstracts met the eligibility criteria, or if they did not provide enough information to enable a decision regarding eligibility to be made. Inclusion was be determined once the full text was read. After review, a total of 36 articles were identified (Figure 1).

Given practical considerations among clinicians and patients with blistering diseases during the COVID-19 pandemic, a brief review of additional considerations for the clinician managing this patient population was also included.

\section{Discussion}

\section{Autoimmune Bullous Disorders}

Autoimmune bullous disorders (AIBD) are acquired diseases resulting from immunologic activity targeting constituents of the skin or mucosa. The spectrum of disease is broad and may range from isolated cutaneous erosions and vesicles to potentially deadly, diffuse sloughing of broad mucocutaneous surfaces. Numerous studies have aimed to assess the impact of AIBD on QOL as outlined in Table 2. For example, a study by Penha et al demonstrated severely impaired QOL in 84 Brazilian patients with various AIBD evidenced by a median DLQI score of $16.0 .^{2}$ The greatest impact was noted on symptoms/ feelings and daily/leisure activities. ${ }^{2}$ This suggests that the impact of AIBD on QOL may be diverse. Historically the emphasis in evaluating QOL was on disease severity but there may be a relationship to disease subtype as well. Here we review studies evaluating QOL in pemphigus, in which QOL has been most studied; BP, the most common AIBD; and other studies which evaluate patients with multiple AIBD subtypes. 
Table 2 Review of Literature of QOL in AIBD, PV, and BP

\begin{tabular}{|c|c|c|c|c|c|c|}
\hline Author & Year & Disease(s) & Study Type & $\begin{array}{l}\text { Sample } \\
\text { Size }\end{array}$ & QOL Instrument Used & Conclusions \\
\hline \multicolumn{7}{|l|}{ Pemphigus } \\
\hline $\begin{array}{l}\text { Mayrshofer } \\
\text { et } \mathrm{al}^{8}\end{array}$ & 2005 & PV & $\begin{array}{l}\text { Cross- } \\
\text { sectional }\end{array}$ & 30 & DLQI & $\begin{array}{l}\text { Overall DLQI score of } 10 \pm 6.7 \text { in } \\
\text { PV patients. }\end{array}$ \\
\hline $\begin{array}{l}\text { Beissert } \\
\text { et } \mathrm{al}^{71}\end{array}$ & 2011 & PV & $\begin{array}{l}\text { Randomized } \\
\text { controlled } \\
\text { trial }\end{array}$ & $\begin{array}{l}94 \text { adults } \\
\text { with mild } \\
\text { to } \\
\text { moderate } \\
\text { PV }\end{array}$ & SF-36 & $\begin{array}{l}\text { No difference in QOL between } \\
\text { mycophenolate mofetil with } \\
\text { corticosteroids vs placebo with } \\
\text { corticosteroids treatment groups. }\end{array}$ \\
\hline $\begin{array}{l}\text { Schultz } \\
\text { et } \text { al }^{15}\end{array}$ & 2019 & PV & $\begin{array}{l}\text { Cross- } \\
\text { sectional }\end{array}$ & 235 & ABQOL, TABQOL & $\begin{array}{l}\text { No difference in } Q O L \text { using } \\
A B Q O L \text { and } T A B Q O L \text { in } \\
\text { rituximab vs non-rituximab } \\
\text { treatment groups. }\end{array}$ \\
\hline Bax et $\mathrm{al}^{14}$ & 2021 & PV & $\begin{array}{l}\text { Cross- } \\
\text { sectional }\end{array}$ & 114 & ABQOL, DLQI, Skindex-29 & $\begin{array}{l}\text { PDAI is superior to ABSIS in } \\
\text { capturing disease severity. }\end{array}$ \\
\hline Segal et $\mathrm{al}^{20}$ & 2021 & PV & $\begin{array}{l}\text { Cross- } \\
\text { sectional }\end{array}$ & 58 & $\begin{array}{l}\text { DLQI, Revised Illness Perception } \\
\text { Questionnaire (IPQ-R), } \\
\text { Multidimensional Scale of Perceived } \\
\text { Social Support (MSPSS) }\end{array}$ & $\begin{array}{l}\text { IPQ-R was highest for cyclical } \\
\text { course and treatment control. } \\
\text { Beliefs in cyclical course, } \\
\text { emotional influence, psychological } \\
\text { cause, and treatment control } \\
\text { correlated significantly with QOL. }\end{array}$ \\
\hline $\begin{array}{l}\text { Calabria } \\
\text { et } \text { al }^{19}\end{array}$ & 2021 & OPV & $\begin{array}{l}\text { Cross- } \\
\text { sectional }\end{array}$ & $\begin{array}{l}30 \text { OPV } \\
\text { patients vs } \\
30 \text { healthy } \\
\text { controls }\end{array}$ & $\begin{array}{l}\text { SF-36, Pittsburgh Sleep Quality Index } \\
\text { (PSQI), Epworth Sleepiness Scale (ESS), } \\
\text { Hamilton Rating Scale for Depression } \\
\text { (HAM-D), and Hamilton Rating Scale } \\
\text { for Anxiety (HAM-A). }\end{array}$ & $\begin{array}{l}\text { Patients with OPV have lower SF- } \\
36 \text { scores and higher PSQI, HAM- } \\
\text { A, and HAM-D scores. No } \\
\text { difference between treatment vs } \\
\text { non-treatment groups with OPV. }\end{array}$ \\
\hline $\begin{array}{l}\text { Tamasi } \\
\text { et } \text { al }^{12}\end{array}$ & 2019 & $\mathrm{PV}, \mathrm{PF}$ & $\begin{array}{l}\text { Cross- } \\
\text { sectional }\end{array}$ & 109 & EQ-5D, DLQI & $\begin{array}{l}\text { No difference in EQ-5D scores } \\
\text { between patients with PV and PF. } \\
\text { Most common EQ-5D dimensions } \\
\text { reported: pain/discomfort ( } 50 \%) \text {, } \\
\text { mobility ( } 43 \%) \text {, and anxiety/ } \\
\text { depression ( } 43 \%) \text {. }\end{array}$ \\
\hline $\begin{array}{l}\text { Paradisi } \\
\text { et al }\end{array}$ & 2009 & Pemphigus & $\begin{array}{l}\text { Cross- } \\
\text { sectional }\end{array}$ & 139 & $\begin{array}{l}\text { SF-36, Skindex-29, } 12 \text { item General } \\
\text { Health Questionnaire }\end{array}$ & $\begin{array}{l}\text { Impaired QOL in pemphigus } \\
\text { patients vs healthy controls on all } \\
3 \text { Skindex- } 29 \text { scales. GHQ } \\
\text { positive in } 39.7 \% \text { suggesting } \\
\text { comorbid psychiatric conditions. }\end{array}$ \\
\hline Rencz et $\mathrm{al}^{7}$ & 2015 & Pemphigus & $\begin{array}{l}\text { Systematic } \\
\text { review and } \\
\text { meta-analysis } \\
\text { of } 16 \text { HRQoL } \\
\text { studies }\end{array}$ & 1465 & $\begin{array}{l}\text { DLQI, Skindex-29, Skindex-17, } \\
\text { Chronic Oral Mucosal Diseases } \\
\text { Questionnaire, SF-36, Activities of } \\
\text { Daily Living }\end{array}$ & $\begin{array}{l}\text { Highest deterioration in role- } \\
\text { physical dimension measured by } \\
\text { SF-36. DLQI ranged from 4-13.8 } \\
\text { with greatest impairments in } \\
\text { symptoms/feelings, daily activities. } \\
\text { Skindex-29 showed similar mean } \\
\text { scores. }\end{array}$ \\
\hline
\end{tabular}

(Continued) 
Table 2 (Continued).

\begin{tabular}{|c|c|c|c|c|c|c|}
\hline Author & Year & Disease(s) & Study Type & $\begin{array}{l}\text { Sample } \\
\text { Size }\end{array}$ & QOL Instrument Used & Conclusions \\
\hline Sung et $\mathrm{al}^{18}$ & 2015 & Pemphigus & $\begin{array}{l}\text { Cross- } \\
\text { sectional }\end{array}$ & 66 & DLQI, GHQ & $\begin{array}{l}\text { Average DLQI score } 10.18 ; 13.45 \\
\text { for patients with active disease, } \\
\text { and } 5.15 \text { for patients in remission. } \\
\text { GHQ positive in } 42 \% \text {. }\end{array}$ \\
\hline $\begin{array}{l}\text { Krain } \\
\text { et } \mathrm{al}^{13}\end{array}$ & 2019 & Pemphigus & $\begin{array}{l}\text { Cross- } \\
\text { sectional }\end{array}$ & 50 & ABQOL, DLQI, Skindex-29, SF-36 & $\begin{array}{l}\text { Changes in PDAI correlated to } \\
\text { changes in ABQOL, Skindex-S, } \\
\text { and Skindex-F scales for all } \\
\text { patients. ABSIS correlated with } \\
\text { Skindex-S for all patients. }\end{array}$ \\
\hline \multicolumn{7}{|c|}{ Bullous pemphigoid } \\
\hline $\begin{array}{l}\text { Kouris } \\
\text { et } \mathrm{al}^{21}\end{array}$ & 2016 & $\mathrm{BP}$ & $\begin{array}{l}\text { Cross- } \\
\text { sectional }\end{array}$ & 57 & $\begin{array}{l}\text { DLQI, Hospital Anxiety Depression } \\
\text { Scale (HADS-scale), Loneliness Scale- } \\
\text { Version } 3 \text { (UCLA) scale }\end{array}$ & $\begin{array}{l}\text { Mean DLQI score } 9.45 \pm 3.34 \text {. } \\
\text { Statistically significant difference in } \\
\text { HADS total and depression } \\
\text { subscale with no difference in } \\
\text { anxiety subscale. Higher scores in } \\
\text { UCLA scale in BP group. }\end{array}$ \\
\hline $\begin{array}{l}\text { Briand } \\
\text { et } \mathrm{al}^{22}\end{array}$ & 2020 & $\mathrm{BP}$ & $\begin{array}{l}\text { Cross- } \\
\text { sectional }\end{array}$ & 60 & ItchyQoL, 5-D Itch Scale Score & $\begin{array}{l}\text { Mean ItchyQOL score was } 56.2 \text { / } \\
\text { I I0; Mean 5-D Itch Scale Score } \\
\text { was } 16.5 / 25.85 \% \text { of patients had } \\
\text { pruritus daily. }\end{array}$ \\
\hline \multicolumn{7}{|c|}{ Multiple AIBD subtypes } \\
\hline Penha et $\mathrm{al}^{2}$ & 2015 & AIBD & $\begin{array}{l}\text { Cross- } \\
\text { sectional }\end{array}$ & 84 & DLQI & $\begin{array}{l}\text { DLQI median score } 16(9-19) \\
\text { indicating severe impairment } \\
\text { specifically on symptoms/feelings, } \\
\text { daily and leisure activities. }\end{array}$ \\
\hline $\begin{array}{l}\text { Heelan } \\
\text { et al' }\end{array}$ & 2015 & AIBD & $\begin{array}{l}\text { Cross- } \\
\text { sectional }\end{array}$ & 94 & $\begin{array}{l}\text { DLQI, Work Productivity, and Activity } \\
\text { Impairment-Specific Health Problem } \\
\text { questionnaires }\end{array}$ & $\begin{array}{l}\text { Severe AIBD impairs QOL more } \\
\text { than mild and moderate AIBD } \\
\text { which results in more work and } \\
\text { activity impairment. }\end{array}$ \\
\hline Bilgic et $\mathrm{al}^{23}$ & 2019 & AIBD & $\begin{array}{l}\text { Cross- } \\
\text { sectional }\end{array}$ & 67 & $\begin{array}{l}\text { Oral Health Impact Profile-I4 (OHIP- } \\
\text { 14) }\end{array}$ & $\begin{array}{l}\text { OHIP-I } 4 \text { scores correlated with } \\
\text { pain and severity scores. }\end{array}$ \\
\hline $\begin{array}{l}\text { Ferries } \\
\text { et } \mathrm{al}^{4}\end{array}$ & 2020 & AIBD & $\begin{array}{l}\text { Cross- } \\
\text { sectional }\end{array}$ & 164 & ABQOL, TABQOL, DLQI, Skindex-29 & $\begin{array}{l}\text { TABQOL was not sensitive to the } \\
\text { type of treatment or change in } \\
\text { disease. ABQOL is sensitive to } \\
\text { change but is poorly correlated } \\
\text { with OSS. ABQOL may not have } \\
\text { a clear advantage over DLQI or } \\
\text { Skindex- } 29 \text {. }\end{array}$ \\
\hline
\end{tabular}

Abbreviations: AIBD, autoimmune bullous disease; PV, pemphigus vulgaris; PF, pemphigus foliaceus; BP, bullous pemphigoid; DLQI, Dermatology Life Quality Index; Medical Outcome SF-36, Study 36-item Short-form Survey; ABQOL, Autoimmune Bullous Disease Quality of Life; TABQOL, Treatment of Autoimmune Bullous Disease Quality of Life; WPAI, WorkProductivity and Activity Impairment; SHP, Specific Health Problem Questionnaire; OHIP-14, Oral Health Impact Profile-I4; IPQ-R, Revised Illness Perception Questionnaire; MSPSS, Multidimensional Scale of Perceived Social Support; PSQI, Pittsburgh Sleep Quality Index; ESS, Epworth Sleepiness Scale; HAM-D, Hamilton Rating Scale for Depression; HAM-A, Hamilton Rating Scale for Anxiety; GHQ-12, 12 item General Health Questionnaire; COMDQ, Chronic Oral Mucosal Diseases Questionnaire; ADL, activities of daily living; HADS-Scale, Hospital Anxiety Depression Scale; UCLA, Loneliness Scale-Version 3. 


\section{Pemphigus}

Pemphigus is a family of autoimmune blistering conditions related to loss of adhesion between keratinocytes. In these conditions, acantholysis, caused by autoantibodies targeting intercellular adhesion molecules, leads to intraepithelial blister formation. Pemphigus vulgaris (PV), the most common form of pemphigus, is associated with epidermolysis above the stratum basalis, resulting in flaccid blisters and erosions. In contrast, pemphigus foliaceus (PF) is associated with superficial erosions and crusting due to epidermolysis within the upper stratum spinosum or granulosum. Less common subtypes of pemphigus include pemphigus vegetans, IgA pemphigus, paraneoplastic pemphigus, and drug-induced pemphigus.

\section{SF-36}

In 2005, Terrab et al first used the SF-36 in a population of 30 pemphigus patients ( $\mathrm{PV} \mathrm{n}=14$, seborrheic pemphigus $n=10, P F n=4$, pemphigus vegetans $\mathrm{n}=2$ ) and found a significant decrease in all mean scores relative to healthy controls. ${ }^{5}$ Most prominent score differences were noted in physical and emotional status suggesting that physical limitations and emotional frustrations may be correlated. These findings also stress the importance of assessing these domains in particular when evaluating patient's QOL. Among a larger population of pemphigus patients $(n=139$, PV $n=112$, PF $n=10$, other $n=4$ ), Paradisi et al found SF-36 scores varied by demographic and disease severity. ${ }^{6}$ Specifically, investigators observed worse physical and mental component scores as measured by limitations in daily activities and feelings of depression in women as compared to men. Further studies are needed to determine why this disparity exists. They also noted lower average scores in patients with 3-4 years' disease duration and patients $>50$ years old suggesting that effect on QOL may have a cumulative effect and that there are specific gender- and age-related factors to consider. ${ }^{6}$ A meta-analysis of 7 studies using SF-36 in pemphigus patients found the most affected dimensions of SF-36 were role-functioning physical (RP), roleemotional (RE), and vitality (VIT). ${ }^{7}$ This study highlights the significant disparities in QOL findings among patients with similar characteristics using the SF-36 and Skindex-29 instruments. This disparity is likely due to lack of pemphigus-specific assessments in these instruments and these patients may benefit from the use of more specific assessment tools. Average SF-
36 scores and conclusions across multiple studies are detailed in Table 2.

\section{DLQI}

A German study in 2005 examined 36 patients with a new diagnosis of $\mathrm{PV}$ across multiple sites and investigators determined that newly diagnosed PV patients had an elevated average DLQI score at $10 \pm 6.7$ as compared to other skin diseases indicating that $\mathrm{PV}$ had a greater impact on QOL. ${ }^{3}$ Ghodsi et al found a similar mean DLQI score of $10.9 \pm 6.9$ in 61 newly diagnosed untreated PV patients in Tehran using the Persian DLQI. ${ }^{9}$ The highest subscores were related to symptoms/feelings (2.8) and daily activities (2.2). Investigators found that DLQI score was significantly increased in patients with severe disease, mucosal involvement, positive Nikolsky sign, and itching. Disease severity and extent of symptoms likely affect ability to partake in daily activities and therefore result in lower QOL. A negative correlation between DLQI score and duration of disease was also noted suggesting increased impairment in the initial stages of the disease. This is further supported by Wysocynska et al who reported an average DLQI of $4.0 \pm 5.9$ in a patient population mainly composed of patients with a $>5$ years of disease. ${ }^{10}$ Patients likely undergo an adjustment period upon initial diagnosis which affects QOL scores early on in disease course. In 2015, a meta-analysis across four studies surrounding QOL in pemphigus patients found a mean DLQI of 12.0 (95\% CI 11.1-12.9) with symptoms/feelings and daily activities subscores most consistently affected. ${ }^{7}$ A summary of DLQI scores reported in the literature evaluating QOL in pemphigus is noted in Table 2.

\section{Skindex-29}

In 2009, Paradisi et al performed the first large study implementing the Skindex-29 among pemphigus patients. ${ }^{6}$ They assessed $112 \mathrm{PV}$ patients who had mean scores of 36 in both the symptoms and emotions domains. They also noted 10 PF patients who had the highest mean scores of 52 in both the symptoms and social functioning domains. ${ }^{6}$ A meta-analysis of 4 studies found similar mean scores in the symptoms and emotion domains, while slightly lower scores for social functioning. ${ }^{7}$ These findings suggest that symptoms and emotional disturbance are most implicated in negative effect on QOL. In a follow-up study, Paradisi et al examined 112 pemphigus patients for treatment-related differences in QOL and found no 
significant difference in Skindex-29 scores. ${ }^{11}$ It is unlikely that different treatment approaches have significant impact on QOL. These findings suggest that the utility of the Skindex-29, like the SF-36 and DLQI, may be limited by its lack of disease specificity or focus on mucosal involvement. Focused assessment of mucosal involvement may provide a more accurate representation of the effect of disease on QOL in conditions that significantly involve mucous membranes.

\section{EQ-5D}

The European Quality of Life Five Dimension (EQ-5D) is a tool that was developed in Europe and used to measure QOL by assessing five dimensions; mobility, self-care, usual activities, pain/discomfort, and anxiety/ depression. One study has investigated the role of the EQ-5D in assessing QOL in pemphigus patients. Tamasi et al evaluated 109 patients with either PV or PF using the EQ-5D and found that the top three dimensions affected were pain/discomfort (50\%), mobility (43\%), and anxiety/depression (43\%). ${ }^{12}$ There was no significant difference in EQ-5D scores of PF versus PV patients. EQ-5D scores significantly varied by disease severity and the number of comorbidities suggesting that these factors play a role not only in disease-related symptoms but psychosocial factors as well both of which negatively impact QOL. Compared to the Autoimmune Bullous Skin Disorder Intensity Score (ABSIS), EQ-5D scores were better correlated with DLQI scores and average reported pain intensity. ${ }^{12}$ This suggests that the EQ-5D may be a valid measure of QOL in pemphigus patients, although comparison studies to disease-specific QOL instruments should be pursued in the future.

\section{$A B Q O L$ and TABQOL}

The ABQOL and TABQOL are evaluation instruments validated for assessing QOL specifically in patients with AIBD. These tools specifically assess patient concerns for mucosal involvement such as relapse and flares, swelling associated with bullae, and the need to change clothing due to drainage from lesions. Assessment of these parameters makes these tools especially useful in assessing bullous disorders. Krain et al examined how the ABQOL, DLQI, Skindex-29, and SF-36 correlate to pemphigus-specific severity indices such as Pemphigus Disease Area Index (PDAI) and ABSIS. ${ }^{13}$ After surveying 50 pemphigus patients, the change in PDAI showed a strong correlation $(\mathrm{r}=0.60-0.79)$ with changes in the ABQOL, Skindex-S, and Skindex-F subscales for all patients suggesting that each assessment is sensitive to symptom changes. ${ }^{13}$ Therefore, any of these tools can be reliably used longitudinally to monitor patient progress. For patients with mucosal involvement $(n=24)$, the change in PDAI showed a strong correlation with changes in the ABQOL and Skindex-S subscale suggesting that these assessments may be particularly useful in evaluating diseases with mucosal involvement. ${ }^{13}$ In regards to treatment outcomes, Bax et al performed a retrospective study evaluating patients with PV and suggested that even a small amount of disease activity may have a significant impact on QOL. ${ }^{14}$ This suggests that even if disease activity appears to be clinically low, patients may still experience a reduction in QOL.

\section{Effect of Treatment on QOL}

Treatment of AIBD often requires travel to treatment facilities often located in urban centers, which may be burdensome for patients living in rural regions, and treatment of the disease itself may carry significant burdens. The TABQOL is a unique tool used to assess treatment burdens on QOL, which have previously been underaddressed. In a study performed by Schultz et al, the ABQOL and TABQOL were used to examine QOL in $235 \mathrm{PV}$ patients treated with rituximab versus nonrituximab modalities. Results demonstrated no difference in QOL among participants treated with rituximab versus those not. ${ }^{15}$ This data suggests that ABQOL and TABQOL were either not sensitive enough to discern differences in the examined population or that there is no net benefit between these treatment modalities on QOL in PV patients. ${ }^{15}$ In contrast, Joly et al found that the DLQI and Skindex-29 scores showed greater improvements in patients assigned to rituximab plus short-term prednisone as compared with those receiving prednisone alone $(\mathrm{p}=0.0411$ and $\mathrm{p}=0.0137$, respectively), suggesting that patients receiving rituximab had improved QOL as compared to the non-rituximab modalities. ${ }^{16}$ In 2021, Werth et al compared rituximab and mycophenolate mofetil in achievement of remission rates. They noted that the estimated mean change from baseline DLQI score was -8.87 points in the rituximab group and -6.00 points in the mycophenolate mofetil group, and a post hoc analysis revealed that $62 \%$ of the patients who received rituximab had a DLQI score of 0 (suggesting no disease-related effects on QOL), while only $25 \%$ of patients receiving mycophenolate mofetil reported a DLQI score of $0 .{ }^{17}$ 
The variations in results suggest the need for further research surrounding the effect of treatment approaches on QOL. Based on current data, we recommend an individualized patient-focused treatment approach specifically taking into account factors such as comorbidities and immunosuppression risk factors, as well as mobility issues, missed work, and commute time. A review of the literature surrounding the use of the ABQOL and TABQOL for assessing QOL is included in Table 2.

\section{Mental Health}

Several studies have assessed psychiatric comorbidities in pemphigus patients. Findings to date vary by assessments used and populations examined. One report using the GHQ-28 on 61 patients with newly diagnosed untreated PV found that more than $77 \%$ of patients experienced anxiety and depression. ${ }^{9}$ Another study of 66 Korean pemphigus patients found that $47 \%$ had a positive GHQ indicating likely comorbid psychiatric conditions. ${ }^{18}$ The Hamilton Rating Scale for Depression and Anxiety (HAM-D, HAM-A) is a 17 item clinicianadministered questionnaire that evaluates symptoms of depression experienced over the preceding week. Using the HAM-D questionnaire, Calabria et al compared 30 patients with oropharyngeal PV (OPV) to healthy controls and showed higher HAM-A and HAM-D scores in patients with OPV. ${ }^{19}$ Moreover, significant sleep impairment was observed in the OPV group, as demonstrated by elevated Pittsburgh Sleep Quality Index (PSQI) scores. Paradisi et al demonstrated that psychiatric comorbidity was associated with worse QOL in pemphigus patients based on SF-36, Skindex-29, and the GHQ-12 scores. $^{11}$ Segal et al demonstrated that the investigated 58 pemphigus patients had realistic illness perception and high perceived social support. ${ }^{20}$ This study also concluded that patients had an improved QOL when they demonstrated understanding of the chronic nature of their condition. This suggests that mental health comorbidities and impaired QOL observed in pemphigus patients may not be as strongly related to the perception of illness or perceived level of social support. Additionally, there is likely benefit to disease education and illness expectation setting at the time of diagnosis.

\section{Pemphigoid}

Pemphigoid describes a family of autoimmune blistering diseases characterized by immunoglobulin and complement deposition within the epidermal and/or mucosal basement membrane zone, resulting in subepithelial blisters. BP and mucous membrane pemphigoid (MMP) are most commonly discussed, while pemphigoid gestationis, anti-p200 pemphigoid, and others are less common. BP presents with subepidermal blistering with rare oral involvement. In contrast, MMP more often presents with smooth-bordered mucosal erosions that result in scarring and is less likely to involve cutaneous surfaces.

\section{Bullous Pemphigoid}

Two studies have investigated QOL in BP patients. A case-control study examining QOL by DLQI, anxiety, and depression in $57 \mathrm{BP}$ patients compared to healthy controls. The Hospital Anxiety Depression (HADS) is a 14-item assessment tool assessed on a Likert Scale measuring anxiety and depression with higher scores indicating more symptoms. Investigators reported a mean DLQI score of $9.45 \pm 3.34$, and a significant difference in the total $(13.68 \pm 5.66$ in the BP group and $11.85 \pm 3.84$ in the control group) and depression subscale $(7.77 \pm 2.36$ in BP group and $6.42 \pm 2.09$ in the control group) of the HADS assessment. ${ }^{21}$ Kouris et al found no difference in the HADS-anxiety subscale between groups. Further studies are needed to explore the effect of BP on the severity of depression and anxiety. BP patients had a higher perceived sense of loneliness as indicated by significantly elevated Loneliness Scale-Version 3 (UCLA) scores compared to controls. ${ }^{21}$ Although mixed, these results suggest impaired QOL and increased mental health comorbidities in BP patients. A second study investigated the role pruritus plays in QOL of 60 French BP patients using the 5-D Itch Scale and the ItchyQOL. ${ }^{22}$ Results showed that $85 \%$ of patients experienced pruritus daily, at a mean severity of 5.2/10. Mean ItchyQOL score was 56.2/100 and 5-D Itchy scale score was $16.5 / 25$ indicating significant QOL impairment due to pruritus which had not been specifically assessed previously. A further review of QOL assessments is outlined in Table 2 .

\section{Studies Including Multiple AIBD Subtypes}

Larger reviews have evaluated multiple AIBD subtypes and their effect on QOL. Ferries et al demonstrated severely impaired QOL in 164 patients with pemphigus, $\mathrm{BP}$, and MMP across multiple sites in France. ${ }^{4}$ Investigators found that the ABQOL correlated with DLQI and Skindex-29 scores, and weakly correlated with 
changes in the PDAI, BPDAI, and MMPDAI. This suggests that the use of ABQOL, DLQI and Skindex-29 are useful in assessing QOL in patients with AIBD. The ABQOL and PDAI were more closely correlated in pemphigus and BP patients than in patients with MMP. ${ }^{4}$ This was attributed to the smaller number of questions specifically focused on mucosal involvement, which may be required to better assess MMP. Heelan et al found a comparably lower mean DLQI of $6.5 \pm 7.3$ among 94 patients with AIBD defined as having PV, PF, IgA pemphigus, BP, MMP, epidermolysis bullosa acquisita, or lichen planus pemphigoides, suggesting a moderate effect on QOL. ${ }^{1}$ They did, however, determine that patients with a higher DLQI score had greater work and overall activity impairment, providing initial evidence that AIBD may not only affect QOL but also work productivity.

In 2019, Bilgic et al examined $67 \mathrm{BP}$ and PV patients for oral health-related QOL using the Oral Health Impact Profile-14 (OHIP-14). They used ABSIS scores to evaluate disease severity with a score of $<17$ suggestive of a moderate course and a score $>17$ suggestive of a significant course. They then used OHIP-14 scores to assess QOL. They found that OHIP-14 scores were higher in active patients with an average score of $42.28 \pm 13.66$ as compared to inactive patients with average scores of $29.08 \pm 12.25 .^{22}$ Higher OHIP-14 scores correlated with pain scores. ${ }^{23}$ This study may suggest oral health is a significant factor in the QOL of BP and PV patients, but large-scale conclusions were limited by response bias. Close monitoring of oral involvement and inclusion of dentists in the multidisciplinary approach of care should be strongly considered and may result in improved QOL outcomes.

\section{Inherited Bullous Disorders Epidermolysis Bullosa}

Although there are many forms of inherited bullous disorders, much of the current literature focuses on epidermolysis bullosa (EB). EB is an inherited skin fragility disorder characterized by structural disruptions at the dermo-epidermal junction or in the basal epidermis. These disruptions result in increased skin fragility. Although multiple phenotypes exist, the most commonly described are epidermolysis bullosa simplex (EBS), junctional epidermolysis bullosa (JEB), and dystrophic epidermolysis bullosa (DEB). EBS is the most common type of $\mathrm{EB}$, and is characterized by trauma- or friction-induced superficial skin blistering, erosions and crusting, most commonly caused by an autosomal dominant, negative missense mutation in keratinocyte proteins KRT5 and KRT14. Patients may exhibit localized (EBS-1), intermediate, or severe EBS. In contrast, DEB subtypes have a disruption in type VII collagen synthesis, classified by a mutation in COL7A1 gene.

\section{Effect of Disease on QOL}

Since the publication of the QOLEB, several studies have analyzed QOL in EBS adult patients, with mean scores ranging from $7.9 \pm 5.3 / 51$ to $13.7 \pm 8.7 / 51 .{ }^{24-26}$ In children, Zigmond et al found a mean score of $15 / 30$ in the Children's Dermatology Life Quality Index (cDLQI) ${ }^{27}$ In a subsequent study, Joen et al evaluated 16 patients using VAS, QOLEB, and total Skindex-29 scores. Mean QOLEB score was $26.62 \pm 7.61$ and higher scores were observed in female patients, patients with hospitalization greater than 7 days, and severe generalized dystrophic epidermolysis bullosa (RDEB-gen sev) ${ }^{28}$ Although these findings were not statistically significant in this study, they suggest that a gender disparity may exist and that increased disease severity as evidenced by prolonged hospitalization likely worsens QOL outcomes. In 2017, Brun et al evaluated 57 patients in France with EBS and found that $73 \%$ of patients reported a moderate to severe impact on their QOL using the cDLQI for children and QOLEB for adults. ${ }^{29}$ The mean QOLEB score was $6.6 \pm 4.9 / 51 .^{29}$ They found that $87 \%$ of patients felt frustrated, $27 \%$ embarrassed, $17 \%$ depressed, 33\% uncomfortable, and $40 \%$ anxious or worried by their disease. ${ }^{29}$ Mean cDLQI score was $8.1 \pm 5.1 / 30$ with $76 \%$ reporting that QoL was affected by pain, $56 \%$ felt sad, and $52 \%$ had to decrease or stop any physical activity because of pain. ${ }^{29}$ These findings suggest a significant psychosocial and emotional effect of disease on QOL and stress the importance of close screening for psychiatric comorbidities. In 2020, Togo et al performed a systematic review of 12 articles and concluded that women and children suffering from EB require closer monitoring than other groups, suggesting the importance of adjusting monitoring based on the demographic of the group treated. ${ }^{30}$ Further studies are needed to assess the differences in QOL disturbance amongst various demographic groups. A further review of QOL assessments is outlined in Table 3.

\section{Effect of Chronic Wounds on QOL}

Patients with EB may develop long-lasting, disfiguring wounds, which likely have a significant negative impact on QOL. Eng et al supported this by showing a correlation 
Table 3 Review of Literature of QOL in EB, Various EB Subtypes and HHD

\begin{tabular}{|c|c|c|c|c|c|c|}
\hline Author & Year & Disease(s) & $\begin{array}{l}\text { Study } \\
\text { Type }\end{array}$ & $\begin{array}{l}\text { Sample Size } \\
\text { (n) }\end{array}$ & QOL Instrument Used & Conclusions \\
\hline \multicolumn{7}{|c|}{ EBS, RDEB, DDEB, JEB } \\
\hline $\begin{array}{l}\text { Horn and } \\
\text { Tidman }^{72}\end{array}$ & 2002 & $\begin{array}{l}\text { EBS, RDEB, } \\
\text { DEB }\end{array}$ & $\begin{array}{l}\text { Cross- } \\
\text { sectional }\end{array}$ & I20 (30 children) & DLQI/ CDLQI & $\begin{array}{l}\text { RDEB affects QOL more than EBS } \\
\text { and DEB as evidenced by DLQI/ } \\
\text { cDLQI scores (mean score of } 18 \text { in } \\
\text { adults and } 22 \text { in children). }\end{array}$ \\
\hline Frew et $\mathrm{al}^{24}$ & 2009 & $\begin{array}{l}\text { EBS, RDEB, } \\
\text { DDEB, JEB }\end{array}$ & $\begin{array}{l}\text { Cross- } \\
\text { sectional }\end{array}$ & 111 & QOLEB & $\begin{array}{l}\text { QOLEB is an EB-specific } Q O L \\
\text { measure with discriminative validity } \\
\text { for all subtypes, construct validity, } \\
\text { internal consistency and reliability } \\
\text { (test-retest reliability) }(\mathrm{p}<0.0 \mathrm{l}) \text {. }\end{array}$ \\
\hline Tabolli et a $\left.\right|^{32}$ & 2009 & $\begin{array}{l}\text { EBS, JEB, } \\
\text { DDEB, } \\
\text { RDEB }\end{array}$ & $\begin{array}{l}\text { Cross- } \\
\text { sectional } \\
\text { postal } \\
\text { survey }\end{array}$ & I25 (46 children) & $\begin{array}{l}\text { SF-36, Skindex-29, GHQ-12, } \\
\text { EuroQol } 5 \text { dimensions, Family } \\
\text { Strain Questionnaire(FSQ) }\end{array}$ & $\begin{array}{l}\text { QOL was decreased and family } \\
\text { burden increased with worse } \\
\text { patient-perceived disease severity } \\
\text { and increased body surface area } \\
\text { involvement in patients with RDEB } \\
\text { and DDEB. Women have worse } \\
\text { QOL based on Skindex-29 and SF- } \\
36 \text { scales. GHQ-positive more } \\
\text { frequently among women ( } 48 \% \text { ) vs } \\
\text { men ( } 16 \%)(p=0.003) \text {. GHQ- } \\
\text { positivity correlated to worse } \\
\text { QOL. }\end{array}$ \\
\hline $\begin{array}{l}\text { Margari } \\
\text { et } \mathrm{al}^{35}\end{array}$ & 2010 & RDEB, EBS & $\begin{array}{l}\text { Cross- } \\
\text { sectional }\end{array}$ & 25 (14 children) & $\begin{array}{l}\text { CBCL, K-SADS-PL, SCL 90, } \\
\text { DLQI }\end{array}$ & $\begin{array}{l}\text { No correlation between clinical } \\
\text { severity and intensity of } \\
\text { psychological disturbance despite } \\
\text { high frequency of psychiatric } \\
\text { symptoms. Togetherness and } \\
\text { affection have a strong and positive } \\
\text { influence and result in increased } \\
\text { coping. Multidisciplinary treatment } \\
\text { approach is recommended. }\end{array}$ \\
\hline Yuen et $\mathrm{al}^{26}$ & 2013 & $\begin{array}{l}\text { EBS, JEB, } \\
\text { DDEB, } \\
\text { RDEB }\end{array}$ & $\begin{array}{l}\text { Cross- } \\
\text { sectional }\end{array}$ & 55 (0 children) & QOLEB & $\begin{array}{l}\text { QOLEB scores correlate with } \\
\text { Skindex- } 29 \text { and SF- } 36 \text {. Dutch } \\
\text { QOLEB is a reliable and valid QOL } \\
\text { instrument. }\end{array}$ \\
\hline Kýrová et $\mathrm{al}^{73}$ & 2013 & $\begin{array}{l}\text { EBS, DDEB, } \\
\text { RDEB, JEB }\end{array}$ & $\begin{array}{l}\text { Cross- } \\
\text { sectional }\end{array}$ & 43 (27 children) & DLQI/ cDLQI & $\begin{array}{l}\text { There is a large to very large impact } \\
\text { of disease on } \mathrm{QOL} \text { with greatest } \\
\text { impact noted in RDEB and EBS. }\end{array}$ \\
\hline $\begin{array}{l}\text { Eismann } \\
\text { et } \mathrm{al}^{74}\end{array}$ & 2014 & $\begin{array}{l}\text { EBS, RDEB, } \\
\text { JEB, DDEB }\end{array}$ & $\begin{array}{l}\text { Cross- } \\
\text { sectional }\end{array}$ & 71 children & ABILHAND-Kids, QOLEB & $\begin{array}{l}\text { Effect on QOL differs based on type } \\
\text { of EB with RDEB having the most } \\
\text { effect, followed by JEB, EBS, and } \\
\text { DDEB. }\end{array}$ \\
\hline
\end{tabular}

(Continued) 
Table 3 (Continued).

\begin{tabular}{|c|c|c|c|c|c|c|}
\hline Author & Year & Disease(s) & $\begin{array}{l}\text { Study } \\
\text { Type }\end{array}$ & $\begin{array}{l}\text { Sample Size } \\
\text { (n) }\end{array}$ & QOL Instrument Used & Conclusions \\
\hline Cestari et $\mathrm{al}^{25}$ & 2015 & $\begin{array}{l}\text { EBS, JEB, } \\
\text { DEB }\end{array}$ & $\begin{array}{l}\text { Cross- } \\
\text { sectional }\end{array}$ & 57 (40 children) & QOLEB & $\begin{array}{l}\text { Impact on QOL is correlated to } \\
\text { disease severity based on QOLEB, } \\
\text { cDLQI and DLQI. Brazilian } \\
\text { Portuguese QOLEB is a valid QOL } \\
\text { instrument. }\end{array}$ \\
\hline Brun et $\mathrm{al}^{29}$ & 2017 & EBS-I & $\begin{array}{l}\text { Cross- } \\
\text { sectional }\end{array}$ & 57 (37 children) & cDLQI, QOLEB & $\begin{array}{l}\text { EBS-I has frequent and severe } \\
\text { neuropathic-type pain, which may } \\
\text { be underrated in effect on QOL. }\end{array}$ \\
\hline $\begin{array}{l}\text { Danescu } \\
\text { et } \mathrm{al}^{75}\end{array}$ & 2019 & $\begin{array}{l}\text { EBS, DEB, } \\
\text { Kindler } \\
\text { syndrome, } \\
\text { JEB }\end{array}$ & $\begin{array}{l}\text { Cross- } \\
\text { sectional }\end{array}$ & 50 (29 children) & QOLEB, DLQI/ cDLQI & $\begin{array}{l}\text { EBDASI scores are strongly } \\
\text { correlated with QOL. DEB was } \\
\text { associated with higher EBDASI and } \\
\text { QOLEB. EBDASI damage disease } \\
\text { score was greater in rural areas. }\end{array}$ \\
\hline $\begin{array}{l}\text { Chernyshov } \\
\text { et al }\end{array}$ & 2020 & $\begin{array}{l}\text { EBS, DEB, } \\
\text { JEB, } \\
\text { unspecified } \\
\text { EB }\end{array}$ & $\begin{array}{l}\text { Cross- } \\
\text { sectional }\end{array}$ & 31 children & $\begin{array}{l}\text { InToDerm-QoL with EB- } \\
\text { specific module }\end{array}$ & $\begin{array}{l}\text { EB-specific modules within the } \\
\text { InToDerm-QoL address EB specific } \\
\text { issues to better estimate effect on } \\
\text { QOL. }\end{array}$ \\
\hline \multicolumn{7}{|c|}{ RDEB and DDEB } \\
\hline Jeon et $\mathrm{al}^{28}$ & 2015 & RDEB & $\begin{array}{l}\text { Cross- } \\
\text { sectional }\end{array}$ & $\begin{array}{l}\text { I3 ( } 3 \text { patients } \\
\text { less than } 7 \text { years } \\
\text { old who } \\
\text { required } \\
\text { assistance with } \\
\text { surveys) }\end{array}$ & $\begin{array}{l}\text { Skindex-29, QOLEB, Visual } \\
\text { Analogue Scale (VAS) on pain } \\
\text { and pruritus and questions } \\
\text { addressing economic burden of } \\
\text { treatment. }\end{array}$ & $\begin{array}{l}\text { RDEB perceived disease severity of } \\
\text { "very severe" had worse QOL by } \\
\text { Skindex- } 29 \text { and QOLEB vs "severe" } \\
\text { RDEB. }\end{array}$ \\
\hline Eng et $\mathrm{al}^{31}$ & 2020 & RDEB & $\begin{array}{l}\text { Cross- } \\
\text { sectional }\end{array}$ & 85 & QoLEB & $\begin{array}{l}\text { Larger wound size correlated to } \\
\text { worse } \mathrm{QOL} \text { in patients with RDEB. }\end{array}$ \\
\hline $\begin{array}{l}\text { Fulchand } \\
\text { et } \mathrm{al}^{34}\end{array}$ & 2021 & DDEB & $\begin{array}{l}\text { Cross- } \\
\text { sectional }\end{array}$ & 42 & Medical Profile Survey QoLEB & $\begin{array}{l}\text { Self-reported severity of disease } \\
\text { correlates with severity of pain but } \\
\text { not with size of wounds or number } \\
\text { of dressing changes. Patients with } \\
\text { severe DDEB reported more } \\
\text { severe internal disease symptoms } \\
\text { and greater analgesic use during } \\
\text { dressing changes. }\end{array}$ \\
\hline \multicolumn{7}{|l|}{ EB } \\
\hline Angelis et $\mathrm{al}^{76}$ & 2016 & $\mathrm{~EB}$ & $\begin{array}{l}\text { Cross- } \\
\text { sectional }\end{array}$ & 204 (83 children) & EuroQol 5-domain (EQ-5D) & $\begin{array}{l}\text { EB has a negative impact on patient } \\
\text { health-related } \mathrm{QOL} \text { and poses } \\
\text { a substantial social/economic } \\
\text { burden with high direct non- } \\
\text { healthcare costs. }\end{array}$ \\
\hline
\end{tabular}

(Continued) 
Table 3 (Continued).

\begin{tabular}{|c|c|c|c|c|c|c|}
\hline Author & Year & Disease(s) & $\begin{array}{l}\text { Study } \\
\text { Type }\end{array}$ & $\begin{array}{l}\text { Sample Size } \\
\text { (n) }\end{array}$ & QOL Instrument Used & Conclusions \\
\hline Togo et $\mathrm{al}^{30}$ & 2020 & EB & $\begin{array}{l}\text { Systematic } \\
\text { Review }\end{array}$ & $\begin{array}{l}\text { NA ( } 12 \text { articles } \\
\text { reviewed) }\end{array}$ & $\begin{array}{l}\text { QOLEB, CDLQI, DLQI, } \\
\text { Skindex-29, SF-36 }\end{array}$ & $\begin{array}{l}\text { RDEB and JEB have greater } \\
\text { impairment of QOL. Women and } \\
\text { children may require unique } \\
\text { monitoring. Patients may benefit } \\
\text { from specific pain management } \\
\text { guidelines. }\end{array}$ \\
\hline $\begin{array}{l}\text { Yazdanshenas } \\
\text { et } \mathrm{al}^{67}\end{array}$ & 2020 & $\mathrm{~EB}$ & $\begin{array}{l}\text { Cross- } \\
\text { sectional }\end{array}$ & 83 & QOLEB & $\begin{array}{l}\text { QOLEB and EB severity scores } \\
\text { were correlated. QOLEB validated } \\
\text { as a QOL assessment tool among } \\
\text { Iranian patients. }\end{array}$ \\
\hline \multicolumn{7}{|l|}{ HHD } \\
\hline $\begin{array}{l}\text { Gisondi } \\
\text { et al }{ }^{36}\end{array}$ & 2005 & HHD & $\begin{array}{l}\text { Cross- } \\
\text { sectional }\end{array}$ & 20 adults & Skindex-29, GHQ-12 & $\begin{array}{l}\text { Patients with HHD had higher } \\
\text { Skindex-29 scores and higher levels } \\
\text { of psychological distress as } \\
\text { compared to other cutaneous } \\
\text { diseases. }\end{array}$ \\
\hline
\end{tabular}

Abbreviations: EBS, epidermolysis bullosa simplex; JEB, junctional epidermolysis bullosa; dystrophic epidermolysis bullosa; severe; RDEB, autosomal recessive dystrophic epidermolysis bullosa; dominant dystrophic epidermolysis bullosa; HHD, Hailey-Hailey disease; DLQI, Dermatology Life Quality Index; CDLQI, Children's Dermatology Life Quality Index; QOLEB, the Quality of Life Evaluation in Epidermolysis Bullosa; SF-36, Medical Outcome Study 36-item Short-form Survey; GHQ-I2, I2 item General Health Questionnaire; FSQ, Family Strain Questionnaire; CBCL, Child Behavior Checklist; K-SADS-PL, Kiddie-Sads-Present and Lifetime Version; SCL 90, Symptom Checklist-90; VAS, Visual Analogue Scale; InTo-DermQoL, the Infants and Toddlers Dermatology Quality of Life.

between larger wound size with worsening skin disease severity and worse QOL in 39 participants with RDEB. ${ }^{31}$ The mean QOLEB score in their study was $20.0 \pm 9$ points. ${ }^{31}$ Similarly, Tabolli et al found a correlation between increased EB body surface area involvement, worsened QOL, and patient-perceived severity of disease using the SF-36 and Skindex-29 assessments. ${ }^{32}$ However, SF-36 mental components scores were similar in patients suffering from EB as those of the normal population. ${ }^{32,33}$ This suggests that although wound size has an effect on QOL, wound size does not appear to directly affect mental health comorbidities.

Although RDEB is more commonly studied, Fulchand et al performed Medical Profile and QOLEB surveys in patients with dominant DEB (DDEB) and found that selfreported severity of disease correlated with the severity of pain in the last 12 months (3.4 with mild disease vs 6.8 with severe disease on medical profile, $\mathrm{p}=0.0002$ ) and a trend toward worse QOLEB score (33.4 vs 24.9 respectively, $\mathrm{p}=0.09$ ) when compared with mild severity participants. The severity of self-reported disease did not correlate with the size of wounds or the number of dressing changes. ${ }^{34}$ Additionally, they noted that patients with severe DDEB had more severe internal disease symptoms, such as difficulty swallowing $(62.5 \%, \mathrm{p}=0.01)$, and greater analgesic use during dressing changes $(4.4 \%$ mild vs $81.3 \%$ severe, $\mathrm{p}<0.001)$, as compared with mild DDEB. ${ }^{34}$ Increased severity of disease and greater systemic involvement correlate to worsened QOL.

Given the potential psychiatric consequences of inherited bullous disorders, it is important to assess for coexistence of mental health comorbidities, which may affect treatment and overall clinical outcomes. Margari et al used clinical interviews and standardized diagnostic protocols according to age to assess the frequency of psychiatric symptoms. They noted a high frequency of psychiatric symptoms $(80 \%)$ in patients suffering from EB, but a relatively small percentage (12\%) who had undergone psychopharmacological or psychotherapeutic treatments. ${ }^{35}$ This disparity between psychiatric symptoms and treatment provides an area of focus that if addressed, could improve patients' QOL substantially.

\section{Hailey-Hailey Disease}

HHD, also known as benign familial pemphigus, benign chronic pemphigus, is an autosomal dominant, 
intraepidermal blistering disorder that affects keratinocyte adhesion caused by a loss-of-function mutation in the ATP2C1 gene. It is characterized by painful blistering with subsequent erosions and frequent superficial infections of flexural surfaces.

A single study investigated the QOL in patients with HHD (Table 3). The study used the Skindex-29 to assess 20 patients and found that the effect on QOL was substantial, with mean Skindex-29 symptom scores at 57.1 and 60.7 with $<4$ and $>/=4$ sites affected respectively. ${ }^{36}$ This study implied that a physician's evaluation may not correlate with a patient's perceived handicap and effect on QOL, therefore aggressive treatments may be warranted even in patients who display seemingly low disease activity.

\section{Considerations of Bullous Diseases During the COVID-19 Pandemic}

The ongoing COVID-19 pandemic has resulted in many concerns surrounding the management of blistering disorders. The utility of telemedicine and virtual visits has become increasingly popular, especially for immunosuppressed AIBD patients, and has become a useful strategy to decrease exposure risk. ${ }^{37-39,40}$ There remains concern over the use of immunosuppressive and immunomodulating treatment and the risk of acquiring SARS-CoV-2 infection. Joly et al noted a higher risk of COVID-19 infection in patients with AIBD among 59 patients in France. ${ }^{39}$ Some providers propose postponing immunosuppressive or immunomodulatory therapies and tapering adjunctive therapies to the lowest effective dose, while other providers state that withdrawal of disease-controlling agents could result in uncontrolled disease activity. ${ }^{41-43}$

Mahmoudi et al found that patients receiving greater than $10 \mathrm{mg} /$ day of prednisolone had a higher risk of COVID-19 and hospitalization. ${ }^{44}$ Additionally, they noted that with each passing month after rituximab infusion, the patient's risk of complication decreased. ${ }^{44}$ On the contrary, Kridin et al found that the risk of developing COVID-19 ( $\mathrm{p}=0.496)$, COVID-19associated hospitalization $(\mathrm{p}=0.499)$, and COVID-19associated mortality $(\mathrm{p}=0.789)$, was similar in patients with pemphigus and the age, sex, and ethnicity-matched healthy control group suggesting that the use of systemic corticosteroids and immunosuppressive adjuvant agents was not associated with worse clinical outcomes. ${ }^{45}$ However, they found the risk of COVID-19-associated mortality was higher among patients with BP $(p=0.023)$ as compared to the same matched healthy control subjects. ${ }^{45}$ Although immunosuppressive and immunomodulating treatments may carry an increased risk of infection, a patient-centered approach advocates for shared decision-making, with a thorough discussion of the risks, benefits, and alternatives to treatment with each patient. ${ }^{46}$

There have been rare reports of flares or new-onset AIBD triggered by the COVID-19 vaccination. ${ }^{47-49}$ Although reports are limited, other AIBD may carry a similar risk. This is not unique to the COVID-19 vaccine, as flares of AIBD have been reported from other vaccines. $^{50-55}$ In addition, flares and new-onset AIBD have been reported from natural COVID-19 infections. $^{56-59}$ Despite the small risk of disease onset or flare with vaccination, individual and public health benefits may outweigh this risk for most patients.

\section{Conclusions}

QOL is an important clinical outcome and should be monitored closely especially in patients suffering from blistering disorders such as AIBD, PV, BP, pemphigoid, EB, and HHD. A variety of validated instruments are available for the clinician to monitor QOL. Some of the primary assessment tools used include DLQI, GHQ-28, SF-36, Skindex-29, ABQOL, TABQOL, QOLEB, InToDermQOL. Based on the current evidence, it appears that the ABQOL and TABQOL may be more sensitive in assessing patients with AIBD, particularly those with mucocutaneous disease because there are questions specifically addressing mucosal involvement. The TABQOL is a unique assessment tool that assesses QOL burdens related to treatment. Among inherited blistering disorders, the QOLEB and InTo-DermQOL were developed specifically to assess adults and children with EB, respectively.

Although many QOL instruments have been validated in numerous languages, there are important limitations. For example, there may be a disparity between clinical disease severity and perceived QOL, which supports the regular use of both sets of instruments to accurately assess the impact of disease on patients' lives. Frequent monitoring of QOL and ensuring appropriate supports are in place are critical to maintaining patient-centered care. Because bullous disorders affect multiple organ systems and may negatively impact mental health, a multidisciplinary approach including mental health providers, primary care physicians, and when relevant, other specialty providers, should be incorporated to improve patients' overall QOL. In addition, providers should not forget the positive role that many patient support groups have on QOL (eg The 
International Pemphigus and Pemphigoid Foundation, The Rare Illness Network, and Dystrophic Epidermolysis Bullosa Research Association "DebRA" International).

Finally, while COVID-19 vaccination, like other forms of vaccination as well as natural infection, may carry a risk of disease flare, we believe that the individual and public health benefits of vaccination typically outweigh potential risks. An informed, individualized discussion should be undertaken to better assess these factors for each patient.

\section{Funding}

This article has no funding Source.

\section{Disclosure}

Dr David Pearson reports personal fees from Biogen Inc, outside the submitted work. The authors report no other potential conflicts of interest for this work.

\section{References}

1. Heelan K, Hitzig SL, Knowles S, et al. Loss of work productivity and quality of life in patients with autoimmune bullous dermatoses. $J$ Cutan Med Surg. 2015;19(6):546-554. doi:10.1177/1203475415582317

2. Penha MÁ, Farat JG, Miot HA, Barraviera SR. Quality of life index in autoimmune bullous dermatosis patients. An Bras Dermatol. 2015;90 (2):190-194. doi:10.1590/abd1806-4841.20153372

3. Patsatsi A, Kokolios M, Kyriakou A, et al. Quality of life in Greek patients with autoimmune bullous diseases assessed with ABQOL and TABQOL indexes. Acta Derm Venereol. 2017;97(9):1145-1147. doi: $10.2340 / 00015555-2737$

4. Ferries L, Gillibert A, Duvert-Lehembre S, et al. Sensitivity to change and correlation between the autoimmune bullous disease quality-oflife questionnaires $\mathrm{ABQOL}$ and TABQOL, and objective severity scores. Br J Dermatol. 2020;183(5):944-945. doi:10.1111/bjd.19173

5. Terrab Z, Benchikhi H, Maaroufi A, Hassoune S, Amine M, Lakhdar H. Qualité de vie et pemphigus [Quality of life and pemphigus]. Ann Dermatol Venereol. 2005;132(4):321-328. doi:10.1016/ s0151-9638(05)79276-0

6. Paradisi A, Sampogna F, Di Pietro C, et al. Quality-of-life assessment in patients with pemphigus using a minimum set of evaluation tools. J Am Acad Dermatol. 2009;60(2):261-269. doi:10.1016/j.jaad.20 08.09.014

7. Rencz F, Gulácsi L, Tamási B, et al. Health-related quality of life and its determinants in pemphigus: a systematic review and meta-analysis. Br J Dermatol. 2015;173(4):1076-1080. doi:10.1111/bjd.13848

8. Mayrshofer F, Hertl M, Sinkgraven R, et al. Deutliche Einschrankung der Lebensqualitat bei Patienten mit Pemphigus vulgaris: ergebnisse der deutschen Bullous Skin Disease (BSD)-Studiengruppe [Significant decrease in quality of life in patients with pemphigus vulgaris. Results from the German Bullous Skin Disease (BSD) Study Group]. J Dtsch Dermatol Ges. 2005;3(6):431-435. doi:10.11 11/j.1610-0387.2005.05722.x

9. Ghodsi SZ, Chams-Davatchi C, Daneshpazhooh M, Valikhani M, Esmaili N. Quality of life and psychological status of patients with pemphigus vulgaris using dermatology life quality index and general health questionnaires. J Dermatol. 2012;39(2):141-144. doi:10.1111/ j.1346-8138.2011.01382.x
10. Wysoczyńska K, Żebrowska A, Waszczykowska E. Quality of life in patients with pemphigus. Dermatology Review/Przeglad Dermatologiczny. 2013;100(3):139-145.

11. Paradisi A, Cianchini G, Lupi F, et al. Quality of life in patients with pemphigus receiving adjuvant therapy. Clin Exp Dermatol. 2012;37 (6):626-630. doi:10.1111/j.1365-2230.2011.04282.x

12. Tamási B, Brodszky V, Péntek M, et al. Validity of the EQ-5D in patients with pemphigus vulgaris and pemphigus foliaceus. $\mathrm{Br}$ J Dermatol. 2019;180(4):802-809. doi:10.1111/bjd.16883

13. Krain RL, Kushner CJ, Tarazi M, et al. Assessing the correlation between disease severity indices and quality of life measurement tools in pemphigus. Front Immunol. 2019;10:2571. doi:10.3389/ fimmu.2019.02571

14. Bax CE, Ravishankar A, Yan D, et al. Identifying the required degree of disease clearance to improve quality of life in pemphigus vulgaris. Br J Dermatol. 2021;184(3):573-575. doi:10.1111/bjd.19625

15. Schultz B, Latour E, Fett N. Quality of life remains poor for patients with pemphigus vulgaris despite targeted therapies. Br J Dermatol. 2019;181(5):1101-1103. doi:10.1111/bjd.18167

16. Joly P, Maho-Vaillant M, Prost-Squarcioni C, et al. First-line rituximab combined with short-term prednisone versus prednisone alone for the treatment of pemphigus (Ritux 3): a prospective, multicentre, parallel-group, open-label randomised trial. Lancet. 2017;389 (10083):2031-2040. doi:10.1016/S0140-6736(17)30070-3

17. Werth VP, Joly P, Mimouni D, et al. Rituximab versus mycophenolate mofetil in patients with pemphigus vulgaris. $N$ Engl J Med. 2021;384 (24):2295-2305. doi:10.1056/NEJMoa2028564

18. Sung JY, Roh MR, Kim SC. Quality of life assessment in Korean patients with pemphigus. Ann Dermatol. 2015;27(5):492-498. doi:10.5021/ad.2015.27.5.492

19. Calabria E, Adamo D, Leuci S, et al. The health-related quality of life and psychological profile in patients with oropharyngeal Pemphigus Vulgaris in complete clinical remission: a case-control study. J Oral Pathol Med. 2021;50(5):510-519. doi:10.1111/jop.13150

20. Segal O, Goldzweig G, Tako E, Barzilai A, Lyakhovitsky A, Baum S. Illness perception, perceived social support and quality of life in patients with pemphigus vulgaris: what should dermatologists know? Acta Derm Venereol. 2021;101(4):adv00441. doi:10.2340/ 00015555-3785

21. Kouris A, Platsidaki E, Christodoulou C, et al. Quality of life, depression, anxiety and loneliness in patients with bullous pemphigoid. A case control study. An Bras Dermatol. 2016;91(5):601-603. doi:10.1590/abd1806-4841.20164935

22. Briand C, Gourier G, Poizeau F, et al. Characteristics of pruritus in bullous pemphigoid and impact on quality of life: a Prospective Cohort Study. Acta Derm Venereol. 2020;100(18):adv00320. doi:10.2340/00015555-3683

23. Bilgic A, Aydin F, Sumer P, et al. Oral health related quality of life and disease severity in autoimmune bullous diseases. Niger J Clin Pract. 2020;23(2):159-164. doi:10.4103/njcp.njcp_216_19

24. Frew JW, Martin LK, Nijsten T, Murrell DF. Quality of life evaluation in epidermolysis bullosa (EB) through the development of the QOLEB questionnaire: an EB-specific quality of life instrument [published correction appears in $\mathrm{Br} \mathrm{J}$ Dermatol. 2010 Mar;162(3):701]. Br J Dermatol. 2009;161(6):1323-1330. doi:10.11 11/j.1365-2133.2009.09347.x

25. Cestari T, Prati C, Menegon DB, et al. Translation, cross-cultural adaptation and validation of the quality of life evaluation in epidermolysis bullosa instrument in Brazilian Portuguese. Int J Dermatol. 2016;55(2):e94-e99. doi:10.1111/ijd.12819

26. Yuen WY, Frew JW, Veerman K, van den Heuvel ER, Murrell DF, Jonkman MF. Health-related quality of life in epidermolysis bullosa: validation of the Dutch QOLEB questionnaire and assessment in the Dutch population. Acta Derm Venereol. 2014;94(4):442-447. doi:10.2340/00015555-1758 
27. Zigmond AS, Snaith RP. The hospital anxiety and depression scale Acta Psychiatr Scand. 1983;67(6):361-370. doi:10.1111/j.16000447.1983.tb09716.x

28. Jeon IK, On HR, Kim SC. Quality of life and economic burden in recessive dystrophic epidermolysis bullosa. Ann Dermatol. 2016;28 (1):6-14. doi:10.5021/ad.2016.28.1.6

29. Brun J, Chiaverini C, Devos C, et al. Pain and quality of life evaluation in patients with localized epidermolysis bullosa simplex. Orphanet J Rare Dis. 2017;12(1):119. doi:10.1186/s13023-0170666-5

30. Togo CCG, Zidorio APC, Gonçalves VSS, Hubbard L, de Carvalho KMB, Dutra ES. Quality of life in people with epidermolysis bullosa: a systematic review. Qual Life Res. 2020;29 (7):1731-1745. doi:10.1007/s11136-020-02495-5

31. Eng VA, Solis DC, Gorell ES, et al. Patient-reported outcomes and quality of life in recessive dystrophic epidermolysis bullosa: a global cross-sectional survey. J Am Acad Dermatol. 2021;85(5):1161-1167. doi:10.1016/j.jaad.2020.03.028

32. Tabolli S, Mozzetta A, Antinone V, Alfani S, Cianchini G, Abeni D. The health impact of pemphigus vulgaris and pemphigus foliaceus assessed using the Medical Outcomes Study 36-item short form health survey questionnaire. $\mathrm{Br} \quad J \quad$ Dermatol. 2008;158 (5):1029-1034. doi:10.1111/j.1365-2133.2008.08481.x

33. Tabolli S, Baliva G, Lombardo GA, et al. Health related quality of life assessment in the routine clinical practice of a dermatology unit. Eur J Dermatol. 2006;16(4):409-415.

34. Fulchand S, Harris N, Li S, et al. Patient-reported outcomes and quality of life in dominant dystrophic epidermolysis bullosa: a global cross-sectional survey [published online ahead of print, 2021 Sep 13]. Pediatr Dermatol. 2021. doi:10.1111/pde.14802

35. Margari F, Lecce PA, Santamato W, et al. Psychiatric symptoms and quality of life in patients affected by epidermolysis bullosa. $J$ Clin Psychol Med Settings. 2010;17(4):333-339. doi:10.1007/s10880-0109205-4

36. Gisondi P, Sampogna F, Annessi G, Girolomoni G, Abeni D. Severe impairment of quality of life in Hailey-Hailey disease. Acta Derm Venereol. 2005;85(2):132-135. doi:10.1080/00015550410025462

37. De Fata Salvatores G, Villani A, Fabbrocini G, Di Guida A. Patients with bullous disorders during COVID-19 period: management and adherence to treatment. Dermatol Ther. 2020;33(6):e13697. doi:10.1111/dth. 13697

38. Villani A, Scalvenzi M, Fabbrocini G. Teledermatology: a useful tool to fight COVID-19. J Dermatolog Treat. 2020;31(4):325. doi:10.1080/09546634.2020.1750557

39. Joly P, Gillibert A, Bohelay G, et al. Incidence and Severity of COVID-19 in patients with autoimmune blistering skin diseases: a nation-wide study [published online ahead of print, 2021 Oct 26]. J Am Acad Dermatol. 2021. doi:10.1016/j.jaad.2021.10.034

40. Gupta R, Ibraheim MK, Doan HQ. Teledermatology in the wake of COVID-19: advantages and challenges to continued care in a time of disarray. J Am Acad Dermatol. 2020;83(1):168-169. doi:10.1016/j. jaad.2020.04.080

41. Shakshouk H, Daneshpazhooh M, Murrell DF, Lehman JS. Treatment considerations for patients with pemphigus during the COVID-19 pandemic. $J$ Am Acad Dermatol. 2020;82(6):e235-e236. doi:10.1016/j.jaad.2020.04.005

42. Schmidt E, Zillikens D. Pemphigoid diseases. Lancet. 2013;381 (9863):320-332. doi:10.1016/S0140-6736(12)61140-4

43. Schmidt E, Kasperkiewicz M, Joly P. Pemphigus. Lancet. 2019;394 (10201):882-894. doi:10.1016/S0140-6736(19)31778-7

44. Mahmoudi H, Farid AS, Nili A, et al. Characteristics and outcomes of COVID-19 in patients with autoimmune bullous diseases: a retrospective cohort study. $J$ Am Acad Dermatol. 2021;84 (4):1098-1100. doi:10.1016/j.jaad.2020.12.043
45. Kridin K, Schonmann Y, Weinstein O, Schmidt E, Ludwig RJ, Cohen AD. The risk of COVID-19 in patients with bullous pemphigoid and pemphigus: a population-based cohort study. J Am Acad Dermatol. 2021;85(1):79-87. doi:10.1016/j.jaad.2021.02.087

46. Schultz B, Pearson DR, Mansh M. Reply to "Treatment considerations for patients with pemphigus during the COVID-19 pandemic. $J$ Am Acad Dermatol. 2021;84(1):e59-e60. doi:10.1016/j. jaad.2020.07.132

47. Damiani G, Pacifico A, Pelloni F, Iorizzo M. The first dose of COVID-19 vaccine may trigger pemphigus and bullous pemphigoid flares: is the second dose therefore contraindicated? J Eur Acad Dermatol Venereol. 2021;35(10):e645-e647. doi:10.1111/jdv.17472

48. Tomayko MM, Damsky W, Fathy R, et al. Subepidermal blistering eruptions, including bullous pemphigoid, following COVID-19 vaccination. $J$ Allergy Clin Immunol. 2021;148(3):750-751. doi:10.1016/j.jaci.2021.06.026

49. Kong J, Cuevas-Castillo F, Nassar M, et al. Bullous drug eruption after second dose of mRNA-1273 (Moderna) COVID-19 vaccine: case report. $J$ Infect Public Health. 2021;14(10):1392-1394. doi:10.1016/j.jiph.2021.06.021

50. Kasperkiewicz M, Woodley DT. Association between vaccination and autoimmune bullous diseases: a systematic review [published online ahead of print, 2021 Apr 24]. J Am Acad Dermatol. 2021. doi:10.1016/j.jaad.2021.04.061

51. Toussirot É, Bereau M. Vaccination and induction of autoimmune diseases. Inflamm Allergy Drug Targets. 2015;14(2):94-98. doi:10.2174/1871528114666160105113046

52. Tavakolpour S. Pemphigus trigger factors: special focus on pemphigus vulgaris and pemphigus foliaceus. Arch Dermatol Res. 2018;310 (2):95-106. doi:10.1007/s00403-017-1790-8

53. Stavropoulos PG, Soura E, Antoniou C. Drug-induced pemphigoid: a review of the literature. $J$ Eur Acad Dermatol Venereol. 2014;28 (9):1133-1140. doi:10.1111/jdv.12366

54. Guerra L, Pedicelli C, Fania L, et al. Infantile bullous pemphigoid following vaccination. Eur J Dermatol. 2018;28(5):708-710. doi:10.1684/ejd.2018.3383

55. Moro F, Fania L, Sinagra JLM, Salemme A, Di Zenzo G. Bullous pemphigoid: trigger and predisposing factors. Biomolecules. 2020;10 (10):1432. doi:10.3390/biom10101432

56. Olson N, Eckhardt D, Delano A. New-onset bullous pemphigoid in a COVID-19 patient. Case Rep Dermatol Med. 2021;2021:5575111. doi:10.1155/2021/5575111

57. Aram K, Patil A, Goldust M, Rajabi F. COVID-19 and exacerbation of dermatological diseases: a review of the available literature [published online ahead of print, 2021 Aug 27]. Dermatol Ther. 2021; e15113. doi:10.1111/dth.15113

58. De Medeiros VLS, Monteiro-Neto AU, França DDT, Castelo Branco R, de Miranda Coelho ÉO, Takano DM. Pemphigus vulgaris after COVID-19: a case of induced autoimmunity [published online ahead of print, 2021 May 27]. SN Compr Clin Med. 2021;1-5. doi:10.1007/s42399-021-00971-8

59. Ghalamkarpour F, Pourani MR. Aggressive course of pemphigus vulgaris following COVID-19 infection. Dermatol Ther. 2020;33 (6):e14398. doi:10.1111/dth.14398

60. Saleh MA, Zaraa I, Doss N, Saleh NA, Murrell DF. Assessment of the quality of life of Egyptian and Tunisian autoimmune bullous diseases' patients using an Arabic version of the autoimmune bullous disease quality of life and the treatment of autoimmune bullous disease quality of life questionnaires. An Bras Dermatol. 2019;94 (4):399-404. doi:10.1590/abd1806-4841.20197198

61. Sebaratnam DF, Okawa J, Payne A, Murrell DF, Werth VP. Reliability of the autoimmune bullous disease quality of life (ABQOL) questionnaire in the USA. Qual Life Res. 2015;24 (9):2257-2260. doi:10.1007/s11136-015-0965-z 
62. Tjokrowidjaja A, Daniel BS, Frew JW, et al. The development and validation of the treatment of autoimmune bullous disease quality of life questionnaire, a tool to measure the quality of life impacts of treatments used in patients with autoimmune blistering disease [published correction appears in Br J Dermatol. 2014 Feb;170(2):481-3]. Br J Dermatol. 2013;169(5):1000-1006. doi:10.1111/bjd.12623

63. Yang B, Chen G, Yang Q, et al. Reliability and validity of the Chinese version of the autoimmune bullous disease quality of life (ABQOL) questionnaire. Health Qual Life Outcomes. 2017;15(1):31. doi:10.1186/s12955-017-0594-z

64. Chen G, Yang B, Zhang Z, et al. Chinese version of the treatment of autoimmune bullous disease quality of life questionnaire: reliability and validity. Indian $J$ Dermatol Venereol Leprol. 2018;84 (4):431-436. doi:10.4103/ijdvl.IJDVL_538_16

65. Teimourpour A, Hedayat K, Salarvand F, et al. Autoimmune Bullous Disease Quality of Life (ABQoL) questionnaire: validation of the translated Persian version in pemphigus vulgaris. Int $J$ Womens Dermatol. 2020;6(4):306-310. doi:10.1016/j.ijwd.2020.03.043

66. Kalinska-Bienias A, Jakubowska B, Kowalewski C, Murrell DF, Wozniak K. Measuring of quality of life in autoimmune blistering disorders in Poland. Validation of disease - specific Autoimmune Bullous Disease Quality of Life (ABQOL) and the Treatment Autoimmune Bullous Disease Quality of Life (TABQOL) questionnaires. Adv Med Sci. 2017;62(1):92-96. doi:10.1016/j. advms.2016.07.002

67. Yazdanshenas A, Naderi E, Moravvej H, et al. The quality of life in epidermolysis bullosa (EB-QoL) questionnaire: translation, cultural adaptation, and validation into the Farsi language. Int $J$ Womens Dermatol. 2020;6(4):301-305. doi:10.1016/j.ijwd.2020.05.012

68. Chernyshov PV, Boffa MJ, Corso R, et al. Creation and pilot test results of the dermatology-specific proxy instrument: the Infants and Toddlers Dermatology Quality of Life. J Eur Acad Dermatol Venereol. 2018;32(12):2288-2294. doi:10.1111/jdv.15229
69. Chernyshov PV, Sampogna F, Pustišek N, et al. Validation of the dermatology-specific proxy instrument the infants and toddlers dermatology quality of life. J Eur Acad Dermatol Venereol. 2019;33 (7):1405-1411. doi:10.1111/jdv.15496

70. Chernyshov PV, Marron SE, Tomas-Aragones L, et al. Initial validation of the epidermolysis bullosa-specific module of the infants and toddlers dermatology quality of life questionnaire. Dermatol Ther. 2020;33(6):e14128. doi:10.1111/dth.14128

71. Beissert S, Mimouni D, Kanwar AJ, Solomons N, Kalia V, Anhalt GJ. Treating pemphigus vulgaris with prednisone and mycophenolate mofetil: a multicenter, randomized, placebo-controlled trial. J Invest Dermatol. 2010;130(8):2041-2048. doi:10.1038/jid.2010.91

72. Horn HM, Tidman MJ. Quality of life in epidermolysis bullosa. Clin Exp Dermatol. 2002;27(8):707-710. doi:10.1046/j.1365-2230.2002.01121.x

73. Kýrová J, Bučková H. Kvalita života pacientů s epidermolysis bullosa. Czecho-Slovak Dermatology/Cesko-Slovenska Dermatologie. 2013;88:3.

74. Eismann EA, Lucky AW, Cornwall R. Hand function and quality of life in children with epidermolysis bullosa. Pediatr Dermatol. 2014;31(2):176-182. doi:10.1111/pde.12262F

75. Dănescu S, Sălăvăstru C, Sendrea A, et al. Correlation between disease severity and quality of life in patients with epidermolysis bullosa. J Eur Acad Dermatol Venereol. 2019;33(5):e217-e219. doi:10.1111/jdv.15371

76. Angelis A, Kanavos P, López-Bastida J, et al. Social/economic costs and health-related quality of life in patients with epidermolysis bullosa in Europe. Eur J Health Econ. 2016;17 Suppl 1(Suppl1):31-42. doi:10.1007/s10198-016-0783-4

\section{Publish your work in this journal}

Clinical, Cosmetic and Investigational Dermatology is an international, peer-reviewed, open access, online journal that focuses on the latest clinical and experimental research in all aspects of skin disease and cosmetic interventions. This journal is indexed on CAS.
The manuscript management system is completely online and includes a very quick and fair peer-review system, which is all easy to use. Visit http://www.dovepress.com/testimonials.php to read real quotes from published authors. 